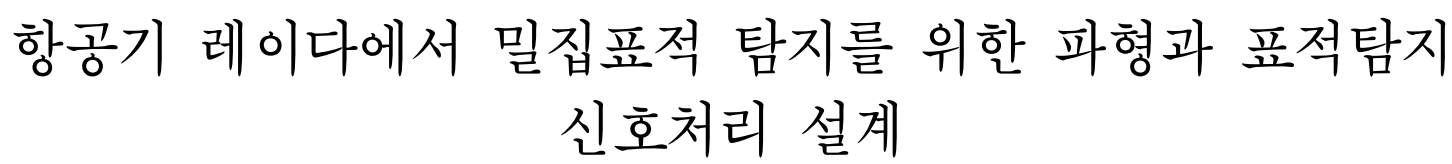

\title{
Design of Waveform and Signal Processing of Target Detection for Detecting Closely Spaced Airborne Targets in Airborne Radar
}

\author{
김태형 · 신종환 · 이성원 · 박준현 · 장성훈 ${ }^{*}$ 김선주* \\ Tae-Hyung Kim $\cdot$ Jong-Hwan Shin $\cdot$ Sung-Won Lee $\cdot$ June-Hyune Park \\ Sung-Hoon Jang* $\cdot$ Seon-Joo Kim* \\ 요 약 \\ 항공기 레이다는 운용자가 공간적으로 밀집된 표적들을 분리해 볼 수 있는 RA(Raid Assessment) 모드를 제공하여, 운 \\ 용자가 추적하고 있는 하나의 표적에 대해 밀집편대의 대수를 파악할 수 있게 하기도 한다. 본 논문은 $\mathrm{AESA(Active}$ \\ Electronically Scanned Array) 레이다를 기반으로 RA 모드 구현을 위한 파형운용과 표적 추출 및 신호처리 등의 설계를 \\ 제시한다. 시뮬레이션과 AESA 레이다를 수송기에 탑재하여 RA 모드를 수행한 비행 시험을 통해 제시한 방법의 기능
} 및 성능을 확인하였다.

\section{Abstract}

Some airborne radars provide the raid assessment mode, which enables the operator to separate closely spaced airborne targets, allowing the operator confirm the number of planes in a dense squadron. This paper presents a design of waveform operation, target extraction, and signal processing method for implementation of the raid assessment mode based on an AESA (active electronically scanned array) radar. The function and performance using our proposed method were confirmed through simulations and a flight test in which the raid assessment mode was conducted with the AESA radar mounted on a cargo aircraft.

Key words: Raid Assessment, Airborne AESA Radar, RA, Air to Air, Flight Test

\section{I. 서 론}

상호지원하며 밀집편대로 비행하는 전투기 표적들은 거의 동일한 거리에서 비슷한 속도로 움직이므로 이런 상황을 고려하지 않은 평범한 파형으로 표적을 탐지/추적 하면, 항공기 레이다는 이런 표적들이 먼 거리에 있을 때
한 개의 표적으로만 탐지한다. 밀집편대로 비행하는 전투 기 표적들을 분리 탐지하기 위해서는 특별히 설계된 파 형의 운용과 신호처리가 필요할 수 있다. 레이다 운용자 의 상황인식에 도움을 주기 위해 항공기 레이다는 추적 하고 있는 한 표적에 대해 실제로 몇 개의 표적이 밀집하 여 비행하고 있는 것인지 평가하는 RA(Raid Assessment)

LIG넥스원(주)(LIG Nex1 Co., Ltd.)

*국방과학연구소(Agency for Defense Development)

- Manuscript received November 19, 2019 ; Revised January 6, 2020 ; Accepted January 22, 2020. (ID No. 20191119-122)

· Corresponding Author: Tae-Hyung Kim (e-mail: thkim07@gmail.com) 
모드를 제공하기도 한다(예로서, AN/APG-65 레이다는 밀 집편대 대수파악 모드인 RA 모드를 제공하고 있다). 즉, 보통의 파형으로 탐지/추적 중인 하나의 표적을, 다시 특 별히 설계된 파형의 운용 등으로 분리 탐지할 수 있도록 하는 기능을 제공하는 것이다. 밀집편대로 비행하는 전투 기를 분리 탐지하기 위해서는 특별히 높은 해상도를 가 지는 파형을 사용해야 하며, 그에 맞는 신호처리 방법이 적용되어야 한다. 높은 해상도의 파형은 하나의 빔(beam) 에 많은 레이다 자원의 할당을 요구한다. 전 방위의 표적 을 탐색/추적해야 하는 보통의 운용 상황에서 RA를 위해 지속적으로 높은 해상도의 파형을 사용할 수 없으며, 전 방위의 표적을 탐지할 수 있도록 레이다 자원을 적절히 할당해야 한다 ${ }^{[3]}$. 그러므로 RA 기능(밀집표적 분리 기능) 이 필요한 상황에서 레이다 운용자에 의해 RA 모드가 선 택되어 RA에 특화된 파형이 운용되도록 해야 할 것이다.

본 논문에서는 $\mathrm{AESA}$ (Active Electronically Scanned Array) 레이다 기반의 RA 모드 기능 구현을 위한 파형 설 계 및 운용과 표적 추출 등의 신호처리 설계를 제시한다. 본 논문에서 사용하는 $\mathrm{AESA}$ 레이다는 버스트(burst) 단위 로 전자식 빔 조향 제어를 하고 전자식 빔 조향이므로 어 느 방향에서든지 즉각적인 빔 조향이 가능하다. 그리고 AESA 안테나 모듈에서 아날로그 채널로 수신 Sum 빔, 및 Diff. Azimuth 빔, Diff. Elevation 빔, Gurad 빔이 형성되 어 나오며, 각 채널의 수신기를 통해 디지털 샘플링된 레 이다 신호를 받아서 처리한다. 이러한 본 논문의 AESA 레이다 및 빔 운용 특징을 고려하여, RA 모드의 표적 탐 지 처리 흐름을 제시하고, 그 주요 처리 단계의 기능 및 알고리즘을 기술한다.

본 논문에서 제시한 방법으로 시뮬레이션 및 비행 시 험을 통해 획득한 시험 결과를 제시한다. $\mathrm{AESA}$ 레이다를 수송기(cargo aircraft)의 램프도어에 설치하고, 램프도어 개방 상태에서 후방으로 송신 신호 방사하여 시험을 하 였다. 표적 항공기로 실제 전투기를 사용하였다.

\section{RA 모드와 표적탐지}

일반적으로 전투기 크기는 $10 \mathrm{~m}$ 에서 $25 \mathrm{~m}$ 사이이며, 레이다에서 전투기 표적을 최적으로 탐지하기 위해서는
이 전투기 크기를 감안하여 적절한 거리해상도를 가져야 할 것이다. 또한 밀집편대로 비행하는 전투기 표적들을 분리 탐지하기 위해서는 이 표적들의 크기를 고려하여 파형의 거리 해상도를 가져가야 할 것이다. 거리 해상도 를 예를 들어 $37.5 \mathrm{~m}$ 로 가지고 간다면, 최적의 조건에서 CFAR(Constant False Alarm Rate) 알고리즘 등을 이용해 서 경사거리로 약 $113 \mathrm{~m}$ (거리 해상도의 3배) 떨어진 두 전투기 표적을 분리할 수 있다 ${ }^{[1]}$. 그래서 거리 해상도가 $37.5 \mathrm{~m}$ 인 파형을 사용하면 경사거리로 $113 \mathrm{~m}$ 이상 떨어 져 밀집편대로 비행하는 전투기들은 분리 탐지할 수 있 을 것이다. 본 논문에서는 RA 모드를 위한 파형으로서 경사거리 방향으로 전투기 크기의 3 배 이상의 거리로 떨 어진 두 표적을 분리 탐지할 수 있는 거리 해상도를 가지 도록 했다.

밀집편대로 비행하는 전투기들이 그림 1 과 같이 방위 방향으로는 거리 $l$ 의 크기만큼 떨어져 있다고 하더라도 경사거리 방향에서 거의 동일한 거리로 비행할 수 있다. 이런 경우는 파형의 거리 해상도가 충분하더라도 경사거 리 방향으로는 분리 탐지할 수 없다. 그림 1 에서 $v_{p}$ 는 플 랫폼 속도, $v_{t}$ 는 표적들의 속도로서 편대 비행을 하면서 두 개의 표적이 같은 속도로 움직이는 것으로 가정하였 다. 그리고 $\theta$ 는 플랫폼 기준으로 $v_{p}$ 벡터 방향과 표적 1 의 (Target 1) 방향 사이의 각도, $(\theta+\Delta \theta)$ 는 플랫폼 기준으로 $v_{p}$ 벡터 방향과 표적 2의(Target 2) 방향 사이의 각도이다. 또한 $v_{p(\theta)}$ 는 표적 1 의 방향으로의 플랫폼 속도, $v_{p(\theta+\Delta \theta)}$ 는 표적 2의 방향으로의 플랫폼 속도이다. 그림 1 에서 볼

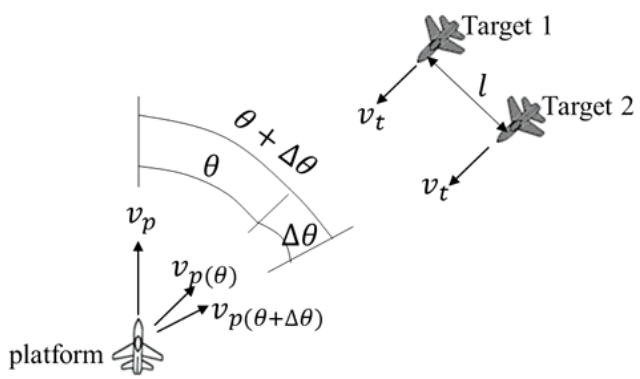

그림 1. RA 모드에서 방위 방향 표적 분리 탐지의 개념

Fig. 1. Concept of detecting by separating targets azimuthdirectionally in RA mode. 
수 있듯이 두 개의 표적을 분리 탐지하기 위해서는 파형 의 방위 해상도를 높여야 할 것이다. 파형의 방위 해상도 를 높이려면 도플러 처리를 통해 획득되는 도플러 해상 도를 높이면 된다. 도플러 해상도는 $P R F / N_{d}$ 로 표현되며, $N_{d}$ 는 한 버스트의 펄스 개수(또는 도플러 필터 개수), PRF는 운용 PRF(Pulse Repetition Frequency)이다. 즉, 도플 러 해상도를 높이려면 한 버스트의 펄스 개수를 증가시 켜서 버스트 시간을 증가시키면 된다. 그림 1에서 두 표 적 사이의 도플러 주파수 차이 $\Delta F$ 는 다음 식과 같다.

$$
\begin{aligned}
\Delta F & \approx\left(\frac{2 v_{p}}{\lambda} \cos (\theta)+\frac{2 v_{t}}{\lambda}\right)-\left(\frac{2 v_{p}}{\lambda} \cos (\theta+\Delta \theta)+\frac{2 v_{t}}{\lambda}\right) \\
& =\frac{2 v_{p}}{\lambda}(\cos (\theta)-\cos (\theta+\Delta \theta))
\end{aligned}
$$

여기서 $\lambda$ 는 전송파장을 나타내며, 표적 1 과 표적 2 사이 의 방위 방향 각도 차이는 $\Delta \theta$ 이다. 그림 1 의 상황에서 CFAR 알고리즘 등을 이용하여 두 표적을 분리 탐지하기 위해서는 $\left(3 \times P R F / N_{d}\right)<\Delta F$ 의 조건 $(\Delta F$ 가 도플러 해 상도의 3 배 이상)을 만족하여야 하며 ${ }^{[1]}$, 이 조건식과 식 (1)에서 방위 방향 표적 분리 탐지를 위해 필요한 최소 버 스트 펄스 수를 다음 식과 같이 구할 수 있다.

$$
\begin{aligned}
& N_{d}>\left(P R F /\left(2 v_{p}(\cos (\theta)-\cos (\theta+\Delta \theta)) / \lambda\right) \times 3\right), \\
& N_{d}>\left(P R F /\left(2 v_{p}(\cos (\theta)-\cos (\theta+l / R)) / \lambda\right) \times 3\right)
\end{aligned}
$$

여기서 두 번째 줄의 식은 플랫폼에서 표적 1 및 표적 2 의 경사거리가 $R$ 이라고 가정하고, $\Delta \theta=l / R$ 임을 이용 하여 구하였다. 식 (2)를 이용하여 그림 1 에서 $l=110 \mathrm{~m}$, $v_{p}=300 \mathrm{~m} / \mathrm{s}, R=60 \mathrm{~km}, P R F=10 \mathrm{kHz}$ 일 때, $\theta$ 값에 따라 두 표적을 분리하기 위해 요구되는 버스트 펄스 수 변화를 그림 2에 나타내었다( $\lambda$ 의 값으로는 $\mathrm{X}$ 밴드의 전송 파장을 사용함). 그림 2에서 $x$ 축은 플랫폼 속도 벡터 기준 으로 표적 위치의 방위각 $\theta$ 를 나타내며, $\mathrm{y}$ 축은 표적을 분 리 탐지하기 위하여 요구되는 최소 버스트 펄스 수를 나 타낸다. 그림 2에서 시나리오에 따라 요구되는 최소 버스 트 펄스 수는 달라질 수 있지만, 표적 위치의 방위각이 클 수록 방위 방향 표적 분리 탐지에 요구되는 버스트 펄스 수가 감소함을 확인할 수 있다. 표적 위치의 방위각이 작 을수록 급격하게 요구되는 버스트 펄스 수가 증가하여 실질적으로 운용하기 어려운 긴 버스트 시간을 요구한다

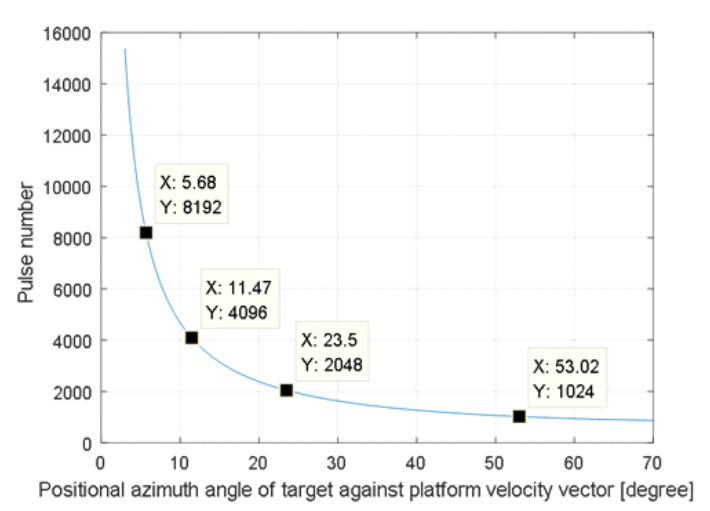

그림 2. RA 모드를 위해 표적 위치의 방위각에 따라 요 구되는 최소 버스트 펄스 수의 예

Fig. 2. Examples of the minimum number of burst pulses required according to azimuth angle of target position for RA mode.

(그림 2에서 버스트 펄스 수가 8,192개이면 버스트 시간 은 $819.2 \mathrm{~ms}$ 이며, 차례로 버스트 펄스 수가 4,096개, 2,048 개, 1,024 개이면 버스트 시간은 $409.6 \mathrm{~ms}, 204.8 \mathrm{~ms}, 102.4$ $\mathrm{ms}$ 이다). 그러므로 모든 시나리오 상황에서 방위 방향 표 적 분리가 가능하도록 RA 모드 파형을 운용하기는 어렵 다. 그러나 플랫폼이 항상 움직이기 때문에 방위 방향 표 적 분리가 가능한 시나리오 상황은 금방 형성된다. 본 논 문에서는 RA 모드를 위한 파형으로서 방위 방향 표적 분 리를 위해 운용 가능한 최대한 펄스 수를 가지는 버스트 를 운용하도록 했다. 버스트 시간을 높이면 표적의 SNR (Signal to Noise Ratio)를 높이는 효과가 있고, 표적의 $\mathrm{SNR}$ 이 높으면 표적을 분리 탐지하는 능력이 높아질 수 있는데, 이것에 대해서는 다음 장에서 자세히 설명한다.

서론에서 언급하였듯이 버스트 시간을 증가시키면 하 나의 빔에 많은 레이다 자원을 할당하게 되어 전 방위 표 적 탐색/추적 성능 저하를 일으킬 수 있다 ${ }^{[3]}$. 그러므로 본 논문에서 제시한 RA 모드를 위한 파형을 사용하려면, 운 용자의 지정에 의해 RA 모드에 진입하고 RA 모드를 위 한 파형을 운영하여 표적을 분리 탐지한 후에 RA 모드를 바로 빠져나와 RA 모드를 위한 파형 사용을 중지하여야 할 것이다. 본 논문에서는 RA 모드를 위한 파형으로서, 거리 해상도는 일반적인 전투기 크기 정도가 되도록 하 고, 버스트 시간은 해당 레이다 시스템이 운용 가능한 최 
대 버스트 펄스 수에 따라 정해지도록 제시한다. 그리고 추적 중인 하나의 표적을 지정하여 RA 모드를 진입하면 $\mathrm{RA}$ 파형을 운영한 후 바로 RA 파형 운영을 중지하고 추 적 중인 표적을 분리 탐지하여 분리 탐지된 표적 개수를 출력하도록 한다.

\section{RA 모드 처리 단계 및 알고리즘 설계}

$\mathrm{AESA}$ 레이다를 기반으로 RA 모드의 기능 구현을 위 해 설계한 처리 단계는 그림 3과 같다. 레이다가 보통의 탐색/추적 모드로 동작하다가, 운용자가 추적 중인 표적 을 지정하고, 그 표적에 대해 RA 모드로 진입하게 된다. 그러면 레이다는 추적 중인 그 표적에 대한 추적 빔에 기 반하여 ${ }^{[3],[4]} \mathrm{RA}$ 파형을 결정하고, RA 빔을 운영한다. RA 빔 운영으로 레이다 반사 신호를 획득하고 신호처리 통 해 몇 대가 편대 비행하고 있는지 표적을 분리 탐지하여 표적 개수 및 플롯 정보를 추출한다. 레이다는 추출된 표 적 개수를 MFD(Multi-Function Display)에 전시하고, RA 모드를 종료한 후 보통의 탐색/추적 모드로 동작한다.

$\mathrm{RA}$ 파형의 버스트 펄스 수는 앞 장에서 설명한 방식으 로 결정되며, RA 빔 운용으로 획득한 레이다 신호에서 밀집한 표적을 분리 탐지하기 위한 적절한 신호처리가 이루어져야 한다. 신호처리 과정은 먼저 신호처리의 편의 를 위해 획득한 레이다 신호에서 플랫폼 속도에 의한 도 플러 속도 성분을 제거한다(platform speed compensation). 그 다음 펄스 압축(pulse compression) 및 거리 셀 이동 보

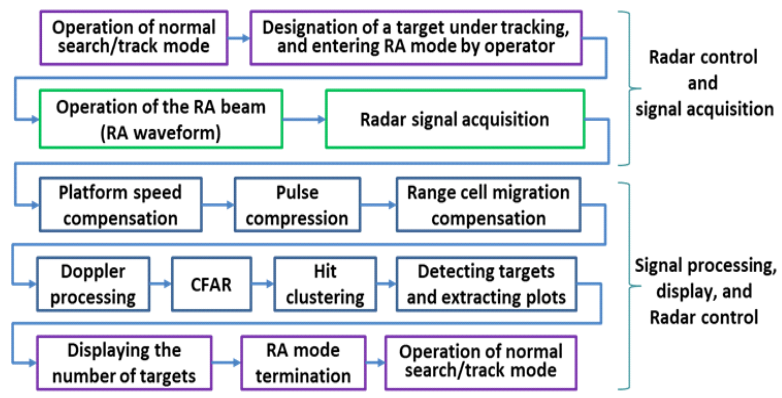

그림 3. RA 모드를 위한 레이다 제어 및 신호처리 흐름

Fig. 3. The flow of radar control and signal processing for RA mode. 상(range cell migration compensation)을 하고, 도플러 처 리를 한다. 여기서 거리 셀 이동 보상이 필요한 이유는 $\mathrm{RA}$ 파형은 긴 버스트 시간을 가지므로 표적이 버스트 시 간 동안 파형의 거리 셀(cell) 해상도보다 더 길게 이동하 게 되어 한 거리 셀에서 표적 정보의 가간섭성(coherency) 이 깨어지기 때문이다. 한 버스트 내에서 펄스마다 적용 되는 거리 셀 이동 보상은 한 표적에 대한 반사 신호가 버스트 내의 펄스마다 동일 거리 셀에 들어오게 하여 한 거리 셀에서 표적 정보의 가간섭성이 유지되게 한다. 거 리 셀 이동보상은 추적 중인 표적의 도플러 속도 값을 이 용하여, 참고문헌 [2]에서 제시한 방법을 사용하여 구현 하였다. 그림 4는 파형의 버스트 시간이 길어짐에 따라
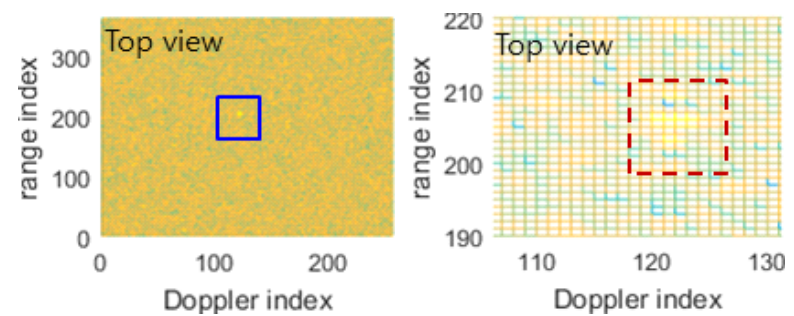

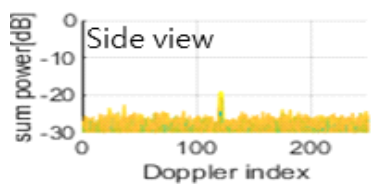

(a)
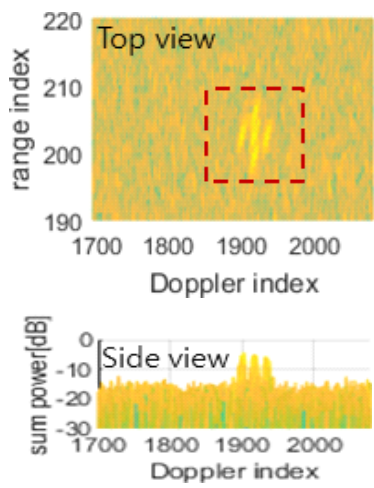

(c)

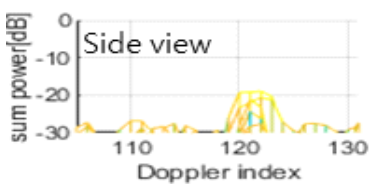

(b)
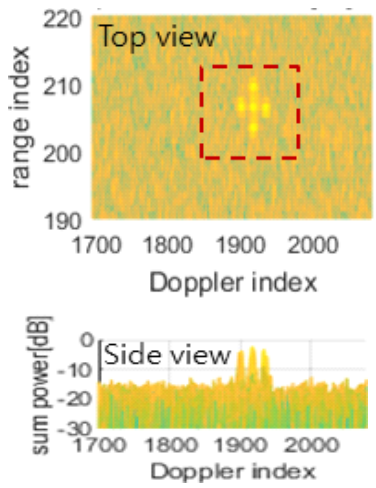

(d)
그림 4. 파형의 버스트 시간과 표적의 거리 셀 이동 및 거리 셀 이동 보상을 통한 가간섭성 유지 효과

Fig. 4. Waveform's burst time and range migrations of targets, and effect of keeping coherency through range cell migration compensation. 
거리 셀 이동 보상이 필요함을 보이고, 거리 셀 이동 보상 의 효과를 보이기 위한 시뮬레이션 결과를 나타낸다. 그 림 4(a)는 플랫폼이 일정한 속도로 비행하고, 5 개의 표적 이 밀집되어 일정한 속도로 비행하는 시나리오에서 표적 방향으로 버스트 시간이 $22.8 \mathrm{~ms}$ 인 파형을 방사한 경우의 시뮬레이션을 통해 획득한 레이다 반사 신호를 플랫폼 속도 보상 및 펄스 압축, 도플러 처리하여 거리/도플러 전 력 맵을 나타낸 것이다(거리 셀 이동 보상 처리는 하지 않음). 그림 4(a)에서 맵을 위에서 본 그림(top view) 및 옆 에서 본 그림(side view)을 차례로 나타내었으며, 사각형 으로 표시된 영역에 표적이 존재한다. 이 사각형 영역을 확대하여 표시한 것이 그림 4(b)이다. 그림 4(b)도 그림 4(a)와 동일한 형식으로 나타냈다. 그림 4(b)에서 보듯이 5 개의 표적에 대한 반사 신호 전력이 분리하기 어렵게 분 포한 것을 알 수 있으며(맵에서 점선 사각형으로 둘러싸 인 부분이 표적이며, 도플러 방향으로 표적 분리가 되지 않고 있음), 표적의 거리 셀 이동에 의한 영향이 없고 표 적의 반사 신호 전력이 동일 거리 셀에 모여 있음을 알 수 있다. 그림 4(c)는 그림 4(b)와 동일한 형식으로 나타냈 다. 그림 4(c)는 그림 4(a)와 동일한 비행 시나리오에서 표 적 방향으로 버스트 시간이 $365.4 \mathrm{~ms}$ 인 파형을 방사한 경 우의 시뮬레이션을 통해 획득한 레이다 반사 신호를 플 랫폼 속도 보상 및 펄스 압축, 도플러 처리하여(거리 셀 이동 보상 처리는 하지 않음) 거리/도플러 전력 맵을 구하 고, 그림 4(a)에 표시한 사각형 영역과 동일한 거리/도플 러 영역을 확대하여 거리/도플러 전력 맵을 나타낸 것이 다. 그림 4(c)에서 보듯이 표적의 거리 셀 이동 현상으로 표적의 반사 신호 전력이 동일 거리 셀에 모여 있지 않고 여러 셀에 걸쳐서 이동되어 분포하고 있으며, 도플러 방 향으로 표적의 반사 신호 전력이 분리되어 나타나지만 CFAR(Constant False Alarm Rate) 처리 등을 통해 분리 탐 지하기 어렵게 신호 전력이 분포되어 있음을 확인할 수 있다(본 논문의 CFAR 알고리즘 설명 참조). 그림 4(d)도 그림 4(b)와 동일한 형식으로 나타냈다. 그림 4(d)는 그림 $4(\mathrm{c})$ 와 동일한 시뮬레이션을 통해 획득한 레이다 반사 신 호를 플랫폼 속도 보상 및 펄스 압축, 거리 셀 이동 보상, 그리고 도플러 처리하여 그림 4(c)와 동일한 거리/도플러 영역을 확대하여 거리/도플러 전력 맵을 나타낸 것이다.
그림 4(d)에서 거리 셀 이동 보상의 효과와 RA 파형과 같 은 긴 버스트 시간을 가진 파형에서 거리 셀 이동 보상이 필요함을 확인할 수 있다. 각 표적 반사 신호 전력들이 각 거리 셀에 모여 있고, 도플러 방향으로도 분리되어 나타 나 있어서 CFAR 처리 등을 통해 분리 탐지하기 용이하게 신호 전력이 분포되어 있다. 거리 셀 이동 보상에 의해 표 적 정보의 가간섭성이 유지되어 한 거리/도플러 셀에 표 적의 전력이 집중되어 표적 탐지에 유리하게 되었다리.

신호처리 과정에서 CFAR 처리는 도플러 처리 이후 획 득되는 거리/도플러 전력 맵에서 표적 전력이 존재하는 위치를 찾는 (Hit) 것으로 ${ }^{[1]}$, 히트(Hit) 위치가 전력 맵에서 표적 위치이다. 본 논문에서는 $\mathrm{CA}($ Cell Average) $\mathrm{CFAR}$ 를 사용하며, 그림 5 와 같이 거리/도플러 전력 맵에서 표적 전력과 부엽 성분의 분포를 고려하여 십자형의 참조(reference) 셀과 경계(guard) 셀들을 가진다. 그림 4(b)와 4(d) 에서 보듯이 표적 전력과 부엽 성분이 십자형으로 존재 함을 확인할 수 있다. 그림 5에서 보듯이 참조 셀들에서 의 전력 값 평균에 일정한 값 $\left(K_{0}\right)$ 을 곱한 값을 문턱치 (threshold)로 하여 표적의 히트 위치(표적 전력이 집중된 위치)를 찾는다. CFAR 처리에서 참조 셀과 경계 셀의 개

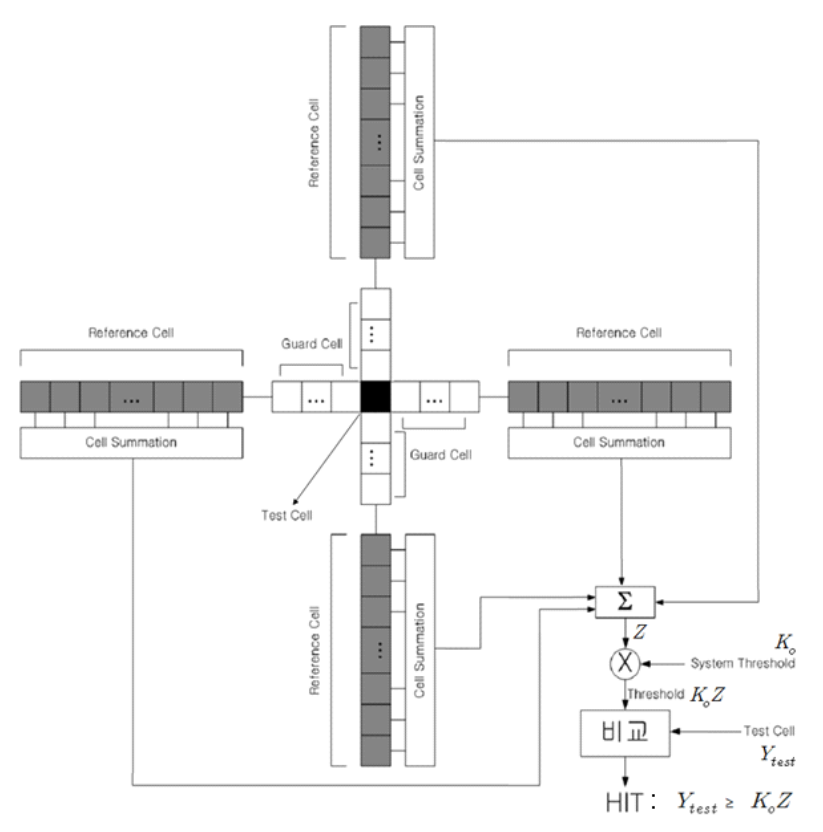

그림 5. $\mathrm{CA} \mathrm{CFAR}$ 알고리즘

Fig. 5. CA CFAR algorithm. 
수 설정이 중요하며, 본 논문에서는 RA 모드의 목적과 군집 표적 탐지를 위해 경계 셀은 십자의 한 쪽에 9개(총 36 개), 참조 셀은 십자의 한 쪽에 64개(총 256개)로 하였 다. 그리고 CFAR 문턱치는 오경보 확률이 $10^{-7}$ 이 되도록 설정하였다 ${ }^{[1,5]}$. 본 논문에서는 $\mathrm{CA} \mathrm{CFAR} \mathrm{처리와} \mathrm{본} \mathrm{논문}$ 의 히트 클러스터링(Hit clustering) 및 문턱치 처리 기법의 최적화된 조합으로 밀집표적 분리 탐지가 이루어지며, 이 런 이유로 CA CFAR가 사용되었다. RA 모드를 위한 효 과적인 밀집표적 분리 탐지를 위해 CA CFAR 경계 및 참 조 셀의 최적 개수 설정과 $\mathrm{CFAR}$ 문턱치에 대한 연구는 더 필요하다.

CFAR 처리 후에 한 표적에 관한 히트들이(표적 전력 과 부엽 성분) 한 곳에 모여서 여러 셀에 나타날 수 있다. 신호처리 과정에서 히트 클러스터링 처리는 이런 한 표 적에 대해 나타나는 여러 히트들을 한 개의 표적으로 묶 고, 그 표적의 대표적 위치를 찾아내는 과정이다. CFAR 처리로 구한 히트 위치에는 표적 전력 값을 히트 위치가 아닌 곳은 영(zero) 값을 저장한 거리/도플러 히트 전력 맵을 이용하여, 이웃한 히트들을 묶어서 히트 클러스터링 처리를 하였다. 그림 6 은 클러스터링을 위한 거리/도플러 셀 검사 순서 및 방법을 표현하였다. 그림 6에서 각 셀(네 모 칸)에 적힌 숫자는 셀 인덱스이다. 2차원 거리/도플러 영역에서 셀 인덱스 순서로 히트를 홇고 검사하면서(그 림 6의 점선 화살표 참조) 이웃한 히트 셀들에게 같은 클 러스터 번호를 부여해 클러스터를 형성해 나간다(같은 클러스터 번호를 가진 셀들이 하나의 클러스터를 형성

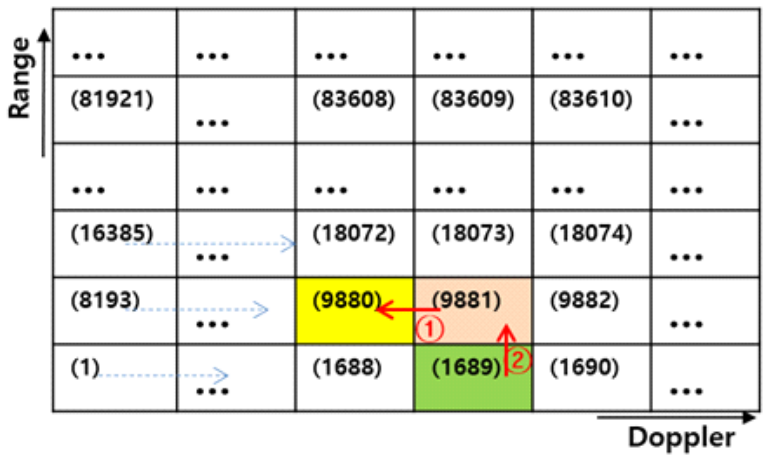

그림 6. 히트 클러스터링에서 이웃 히트들을 묵는 방법

Fig. 6. How to bind neighbor hits in hit clustering.
한 것임). 셀에 클러스터 번호를 부여할 때 2단계 과정을 거친다. 첫 번째 단계는 첫 셀부터 시작하여 마지막 셀까 지 차례로 셀 위치에 저장된 전력 값을 검사하여 문턱치 (이 문턱치는 CFAR 문턱치가 아님, 묶음 문턱치라고 호 칭함) 이상이면 그 셀(묶음 문턱치 이상의 전력을 가진 셀)에 클러스터 번호를 부여해 나가는데, 그 셀의 좌측 (음의 도플러) 방향의 이웃 셀에 클러스터 번호 부여되어 있으면 이웃한 셀에 부여된 그 클러스터 번호를 부여하 고, 이웃 셀에 클러터 번호가 부여되어 있지 않으면 새로 운 클러스터 번호를 부여한다(그림 6에서는 예로서 9881 번 셀에 클러스터 번호를 부여하고자 할 때 실선 화살표 (1)과 같이 이웃한 9880 번 셀에 클러스터 번호 부여 여부 를 검사함을 표현하였다). 두 번째 단계는 이웃한 클러스 터들을 묶는 단계로서 첫 셀부터 시작하여 마지막 셀까 지 차레로 셀에 클러스터 번호가 부여되었는지 확인하여 부여되었으면 이웃한 클러스터를 하나의 클러스터로 묶 는 작업을 한다. 그림 6에서 실선 화살표 (2)는 이웃한 클 러스터를 묶을 때 검사하는 이웃 셀의 예를 보여준다. 1689 번 셀에 클러스터 번호가 부여되었음을 확인하고, 이 셀의 위쪽 (양의 거리) 방향의 이웃 셀인 9881번 셀에 클 러스터 번호가 부여되어 있으면 두 셀에 부여된 클러스 터 번호를 비교한다. 두 셀에 같은 클러스터 번호가 부여 되었으면 아무 작업을 하지 않고 넘어간다. 두 셀에 다른 클러스터 번호가 부여되어 있으면 두 셀이 속해 있는 클 러스터들 내의 모든 셀에 동일한 클러스터 번호(클러스 터 번호로서 두 셀에 부여되어 있던 클러스터 번호 중에 서 작은 값을 선택함)를 부여하여 하나의 클러스터로 묵 는다. 이렇게 클러스터를 형성하고 클러스터 내의 셀들에 부여된 전력 값과 셀의 위치 정보로 클러스터의 대표 위 치 및 대표 전력 값을 계산하여 표적의 위치 및 전력 값 을 추출한다. 히트 클러스터링 과정에서 사용하는 묶음 문턱치는 군집 표적의 분리 탐지 및 오표적 제거에 중요 한 역할을 한다. RA 파형의 긴 버스트 시간에 의해 표적 $\mathrm{SNR}$ 이 높아지는 효과를 고려하고, 효과적인 군집 표적 분리 탐지 및 오표적 제거를 위해 본 논문에서 묶음 문턱 치를 식 (3)과 같이 설정한다.

$$
P_{\text {Max Hit }}(b) / Y_{0}
$$


여기서 $P_{M a x H i t}(b)$ 는 버스트 $b$ 의 거리/도플러 히트 전력 맵에서 가장 높은 전력이 저장된 히트 위치의 전력 값을 나타내며( $b$ 는 버스트 인덱스), $Y_{0}$ 는 양의 실수 값이다. 만 약 $10 \times \log 10\left(Y_{0}\right)$ 가 6이 되도록 $Y_{0}$ 의 값을 설정했다면, 표적 히트 위치의 전력 값들 중의 가장 큰 값에서 $6 \mathrm{~dB}$ 를 낮춘 값이 묶음 문턱치가 된다. 빔 조향한 군집 표적들의 $\mathrm{SNR}$ 이 간섭 신호나 부엽 성분들보다 상대적으로 크고 $\mathrm{RA}$ 파형에 의해 표적 $\mathrm{SNR}$ 이 높아지는 효과가 있기 때문 에 표적의 최고 전력 값을 기준으로 몇 $\mathrm{dB}$ 낮은 값을 묶 음 문턱치로 하면 상대적으로 적은 전력의 부엽 성분이 나 간섭 신호들은 처리할 히트에서 삭제되어 표적 분리 탐지 및 오표적 제거가 이루어지게 된다. 그러므로 RA 파형에 의한 SNR 상승이 표적 분리 탐지에 유리하게 작 용한다. 그림 7은 본 논문의 히트 클러스터링 성능 및 식 (3)의 묶음 문턱치 적용 효과를 설명하는 그림이다. 그림 7(a)는 그림 4(d)와 동일한 시뮬레이션 상황에서 획득한 데이터를 그림 4(d)와 동일한 처리 과정까지 처리한 후의 거리/도플러 전력 맵이다. 그림 7(b)는 그림 7(a)에 CFAR 처리를 수행하여 구한 거리/도플러 히트 맵이다. 그림 7

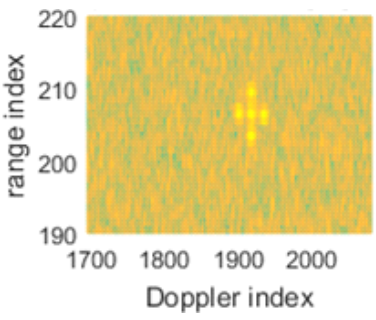

(a)

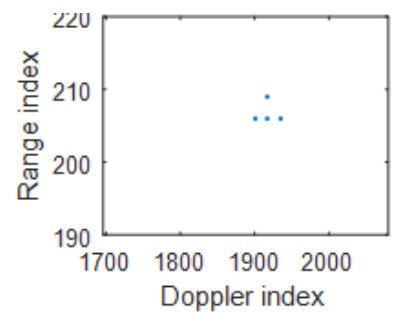

(c)

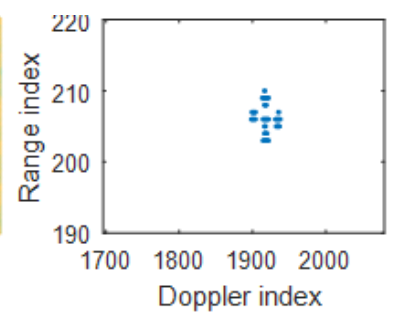

(b)

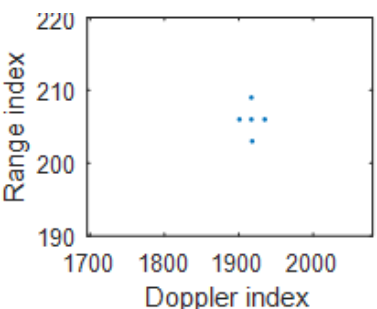

(d)
그림 7. RA 모드용 히트 클러스터링에 의한 군집 표적 분리 탐지 시뮬레이션

Fig. 7. Simulation to separate and detect cluster targets by hit clustering for RA mode. (c)는 묶음 문턱치로서 잡음 전력 값을 사용하여 히트 클 러스터링 처리를 수행하고 구한 각 클러스터들의 대표 위치를 거리/도플러 영역에 표현한 맵이다. 이런 각 클러 스터들의 대표 위치가 각 표적이 탐지된 위치이다(이후 로 본 논문에서는 그림 7(c)와 같은 맵을 거리/도플러 클 러스터 맵이라고 부를 것이다). 그림 7(d)는 식 (3)에서 $10 \times \log 10\left(Y_{0}\right)$ 가 6이 되는 $Y_{0}$ 의 값으로 설정해 구해지 는 묶음 문턱치를 사용하여 히트 클러스터링 처리를 수 행하고 구한 거리/도플러 클러스터 맵이다. 그림 7(c)에서 보면 표적 5 개가 모두 탐지되지 못하고 4 개로 탐지되었 다. 이는 그림 7(b)에서 보듯이 아래쪽에 두 표적에 대한 히트들이 (표적 전력의 부엽 성분으로 인해) 서로 인접해 붙어 있기 때문에 두 표적이 하나의 클러스터로 클러스 터링 되었기 때문이다. 즉, 단순히 잡음 전력을 묶음 문턱 치로 사용하면 분리되어 클러스터링 되지 않는다. 그림 7(d)에서 식 (3)의 방법으로 구한 묶음 문턱치를 사용해 5 개의 표적이 온전히 분리 탐지됨을 확인할 수 있다.

히트 클러스터링으로 표적이 분리 탐지되면, 그림 3의 처리 과정에서 보듯이 탐지된 위치의 표적 정보들을 추 출하여 표적 플롯을 형성하고, 탐지된 표적 개수를 전시 한 다음 RA 모드를 종료한다. 그리고 레이다는 기존의 탐색/추적 모드로 동작하게 된다.

\section{RA 모드 기능 비행시험 결과}

$\mathrm{AESA}$ 레이다에 기반한 RA 모드 기능 시험을 위해 본 논문에서 제시한 파형 및 신호처리 알고리즘 설계에 따 라 RA 모드를 구현하고, 그 기능을 확인하였다. AESA 레 이다를 수송기의 램프도어에 설치하고 램프도어 개방 상 태에서 후방으로 송신 신호를 방사했다. 그리고 표적기로 서 편대 비행하는 두 대의 전투기가 사용되었다. 그림 8 은 본 논문에서의 비행시험 환경을 표현한 그림이다. 일 반적으로 항공기 레이다는 항공기의 앞 쪽에 장착되어 항공기가 이동하는 방향으로 빔을 방사하지만(전방 방 사), 본 논문의 비행시험은 수송기의 뒤쪽으로 빔을 방사 하면서(후방 방사) 획득하므로 비행기의 이동방향과 빔 의 방사방향이 반대가 된다. 후방으로 빔을 방사하면 항 공기의 앞 쪽으로 빔을 방사할 때와는 반대로 지면 클러 


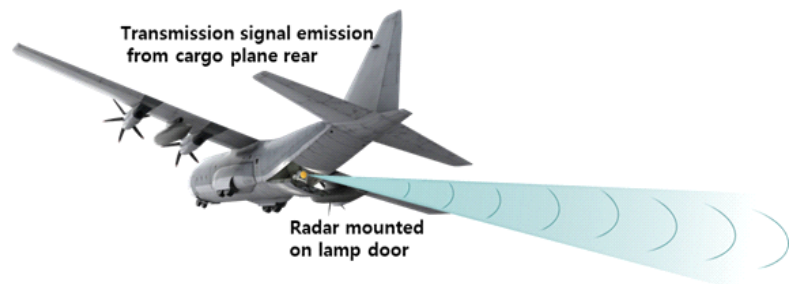

그림 8. $\mathrm{AESA}$ 레이다의 수송기 탑재 시험 환경 형상

Fig. 8. Configuration for flight tests of AESA radar installed on cargo aircraft.

터 반사 신호의 도플러가 형성되지만, RA 모드를 위한 기능 구현에는 차이가 없다. 그림 9는 비행시험으로 획득 한 데이터를 그림 3의 도플러 처리까지 수행하여 구한 거 리/도플러 전력 맵을 보인 것이다. 그림 9(a)는 레이다에 서 약 $40 \mathrm{~km}$ 떨어진 거리의 편대 비행하는 두 대의 전투기 를 추적하는 빔으로 획득한 레이다 반사 신호를 처리하 여 구한 거리/도플러 맵이다. 그림 9(a)에서 실선 사각형 영역이 거리/도플러 영역에서 표적 신호가 있는 영역이 며, 그림 9(a)의 사각형 영역을 확대하여 보인 것인 그림 9(b)이다. 보통의 해상도를 가지는 파형으로 획득한 레이 다 반사 신호로는 두 대의 표적에 대한 신호 전력이 분리 되지 않고 하나로 뭉쳐져 있는 것을 확인할 수 있다. 그림 9(c)는 그림 9(a)에서 추적 중인 표적에 대해 RA 모드를 수행하여 RA 파형의 빔으로 획득한 레이다 반사 신호를 처리하여 거리/도플러 전력 맵을 보인 것이다. 그림 9(c) 의 실선 사각형 영역이 표적 신호가 있는 영역이며, 그림 9 (c)의 사각형 영역을 확대하여 보인 것이 그림 9 (d)이다. 그림 9(b)에서 분리되어 보이지 않던 두 표적이 RA 파형 을 사용하니 그림 $9(\mathrm{~d})$ 에서 분리되어 보이는 것을 확인할 수 있다. 그림 9(e)는 그림 9(b)의 거리/도플러 맵을 옆에 서 본 그림(side view)이다. 그림 9(f)는 그림 9(d)의 거리/ 도플러 맵을 옆에서 본 그림이다. 그림 10(a)는 그림 9(c) 의 거리/도플러 전력 맵 데이터에 대하여 CFAR 처리를 행한 결과인 거리/도플러 히트 맵이다. 그림 $10(\mathrm{a})$ 의 점선 사각형 영역이 두 대의 전투기에 대한 표적 히트들이 있 는 영역이며, 이 영역을 확대한 그림이 그림 $10(\mathrm{~b})$ 이다. 그림 10(b)에서 보면 표적의 부엽 전력 때문에 두 개의 표 적에 대한 히트들이 하나로 뭉쳐서 나타난 것을 볼 수 있

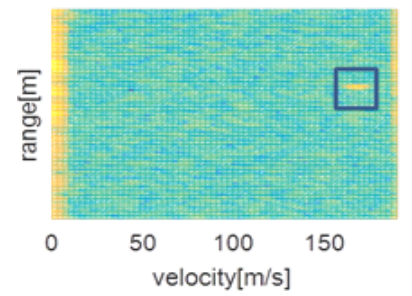

(a)

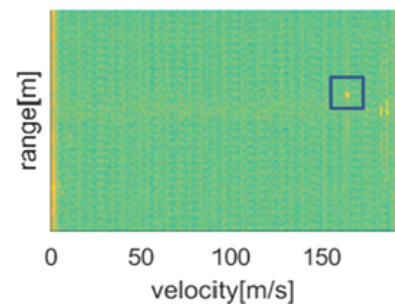

(c)

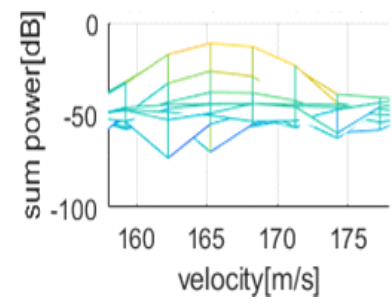

(e)

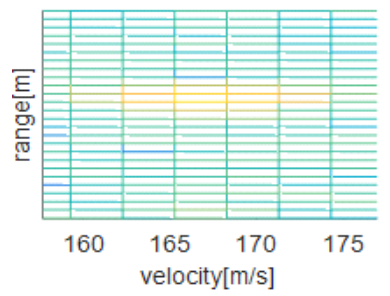

(b)

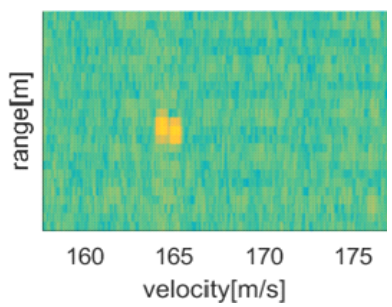

(d)

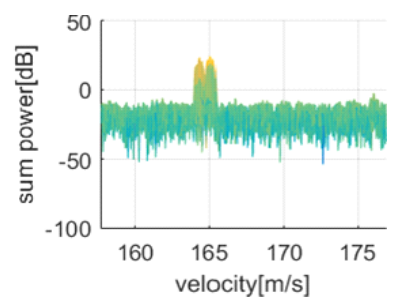

(f)
그림 9. $\mathrm{AESA}$ 레이다의 수송기 탑재와 편대 비행하는 2 대의 전투기를 이용한 RA 모드 기능 시험을 통 해 획득한 비행시험 데이터를 처리하여 구한 거 리/도플러 전력 맵

Fig. 9. Range/Doppler power map obtained by processing flight test data obtained through RA mode function test using 2 flying fighters and AESA radar (installed on cargo aircraft).

다. 그림 $10(\mathrm{c})$ 는 그림 $9(\mathrm{c})$ 의 거리/도플러 전력 맵 데이터 에 대하여 CFAR 처리와 히트 클러스터링 처리까지 수행 한 결과인 거리/도플러 클러스터 맵이다. 그림 10(c)에서 보듯이 식 (3)으로 주어지는 묶음 문턱치에 의해 그림 10(a)에 있던 오탐지 표적들의 히트들이 모두 사라진 것 을 볼 수 있다. 그림 $10(\mathrm{c})$ 의 점선 사각형 영역의 표적이 존재하는 영역을 확대한 것이 그림 $10(\mathrm{~d})$ 이다. 그림 $10(\mathrm{~d})$ 에서 볼 수 있듯이 그림 10(b)에서는 뭉쳐진 히트들로 두 표적이 분리되어 보이지 않았으나, 식 (3)의 묶음 문턱치 에 의해 두 표적으로 분리되어 클러스터링 되고 탐지되 


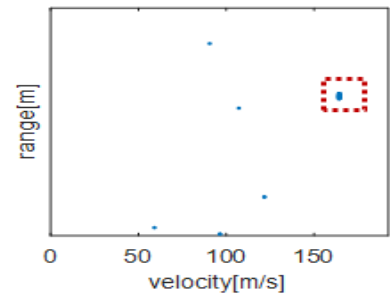

(a)

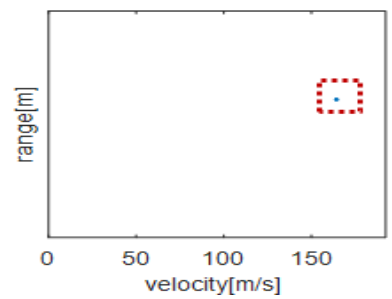

(c)

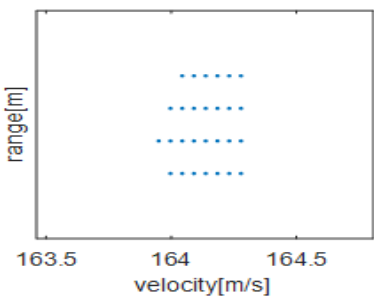

(b)

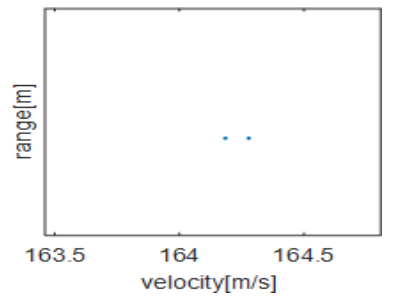

(d)
그림 10. RA 모드 비행시험 데이터를 CFAR 처리 및 히 트 클러스터링 처리를 수행한 결과 1

Fig. 10. Results 1 of performing CFAR processing and hit clustering processing for RA mode flight test data.

었음을 확인할 수 있다. 그림 11은 그림 9의 시나리오 상 황에서 시험하고 그림 $9(\mathrm{c})$ 의 시점 이후 약 20 초 지난 시 점에서 RA 모드를 운영하여 획득한 레이다 반사 신호를 처리하여 거리/도플러 전력 맵을 보인 것이다. 그림 9(c) 와 그림 9(d)의 관계와 동일하게 그림 11(a)와 그림 11(b) 를 나타내었다. 그림 11(b)에서 확인할 수 있듯이 플랫폼 및 표적들의 움직임에 의해 그림 $9(\mathrm{~d})$ 에 비해 표적 분리 가 유리하게 상황이 바뀌었다. 그림 11(c)는 그림 11(b)의 거리/도플러 맵을 옆에서 본 그림이다. 그림 12(a)는 그림 11(a)의 거리/도플러 전력 맵 데이터에 대하여 CFAR 처 리를 행한 결과인 거리/도플러 히트 맵이다. 그림 12(a)의 점선 사각형 영역의 표적 히트들을 확대한 것이 그림 12 (b)이다. 그림 12(b)를 보면 2개의 표적에 대한 히트들 이 2 개의 그룹으로 잘 분리되어 나타난 것을 볼 수 있다. 그림 12(c)는 그림 11(a)의 거리/도플러 전력 맵 데이터에 대하여 CFAR 처리와 히트 클러스터링 처리까지 수행한 결과인 거리/도플러 클러스터 맵이다. 그림 12(a)에 있던 오탐지 표적들의 히트들이 모두 사라진 것을 볼 수 있다. 그림 12(c)의 점선 사각형 영역을 확대한 그림 12(d)에서 볼 수 있듯이 식 (3)의 묶음 문턱치에 의해 두 표적으로

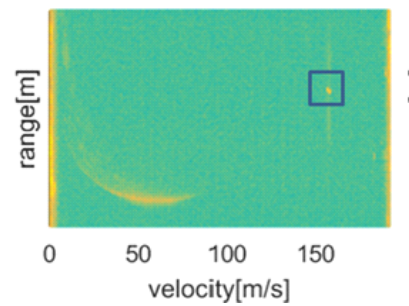

(a)

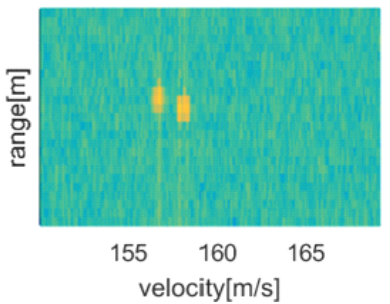

(b)

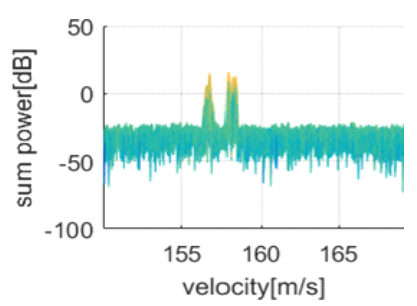

(c)

그림 11. 그림 9와 같은 RA 모드 시험으로 얻은 비행시 험 데이터를 처리하여 구한 거리/도플러 전력 맵

Fig. 11. Range/Doppler power map obtained by processing flight test data obtained through RA mode test such as Fig. 9.

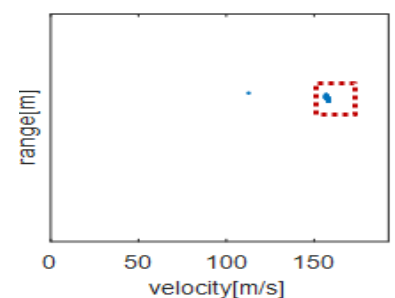

(a)

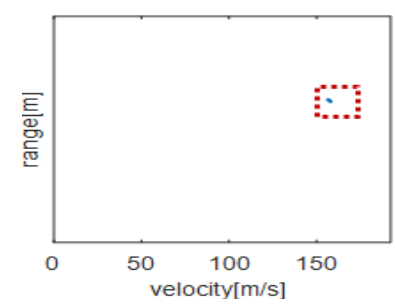

(c)

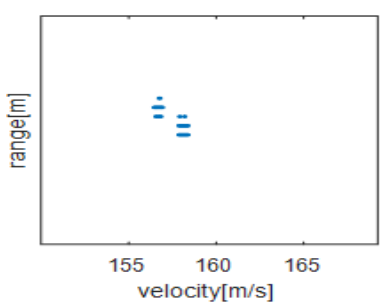

(b)

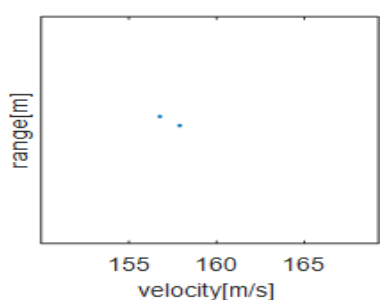

(d)
그림 12. RA 모드 비행시험 데이터를 CFAR 처리 및 히 트 클러스터링 처리를 수행한 결과 2

Fig. 12. Results 2 of performing CFAR processing and hit clustering processing for RA mode flight test data.

분리 탐지가 잘 되었음을 확인할 수 있다. 


\section{V. 결 론}

$\mathrm{AESA}$ 레이다에 기반한 RA 모드 구현을 위하여 RA 파 형의 설계 및 운용 방법을 보이고, 표적 분리 탐지와 정확 한 표적 개수 탐지를 위한 신호처리 알고리즘 설계를 제 시하였다. 제시한 RA 파형 운용 및 신호처리 알고리즘의 기능/성능을 시뮬레이션을 통해 신호 처리 단계별로 확인 했다. 도플러 해상도를 높인 RA 파형으로 동일 거리에 있는 편대 비행하는 표적을 도플러 차이로 분리 탐지할 수 있었으며, RA 파형이 표적의 $\mathrm{SNR}$ 을 높이는 효과를 이 용한 CFAR 및 히트 클러스터링 처리 등의 제시한 알고리 즘이 표적 분리 탐지에 효과가 있음을 실측데이터를 이 용하여 검증 및 확인하였다. 즉, $\mathrm{AESA}$ 레이다의 수송기 탑재 비행시험의 수행 결과로부터 제시한 방법이 편대 비행하는 전투기 표적을 효과적으로 분리 탐지할 수 있 음을 확인하였다.

김 태 형 [LIG넥스원/연구원]

https://orcid.org/0000-0002-5296-2389

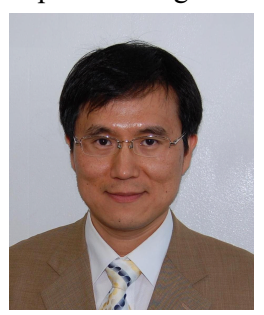

1999년 3월: 부산대학교 전자공학과 (공학 석사)

2007년 3월: 부산대학교 전자공학과 (공학 박사)

2010년 11월: 국방과학연구소 연구원

2010년 12월 현재: LIG넥스원(주) 레이 다연구소 수석연구원

[주 관심분야] 레이다 신호처리, 레이다 시스템, 패턴인식 등

\section{References}

[1] B. R. Mahafza, Radar Systems Analysis and Design Using MATLAB, 2nd ed. Boca Raton, FL, Chapman \& Hall/CRC, 2005.

[2] T. H. Kim, J. G. Seo, J. S. Yoon, and J. H. Bae, "Range cell migration compensation for coherent integration in air-to-air mode of aircraft radar," in Proceedings of the Korea Institute of Military Science and Technology 2017, Jeju, Jun. 2017, pp. 151-153.

[3] T. H. Kim, E. H. Kim, and S. W. Lee, "Real-time PRF selection for search/track in MPRF waveform airborne radar," The Journal of Korean Institute of Electromagnetic Engineering and Science, vol. 25, no. 10, pp. 10501061, Oct. 2014.

[4] G. V. Morris, L. Harkness, Airborne Pulsed Doppler Radar, 2nd ed. Norwood, MA, Artech House, 1988.

[5] M. A. Richards, Fundamentals of Radar Signal Processing, New York, NY, McGraw-Hill, 2005.

신 종 환 [LIG넥스원/연구원]

https://orcid.org/0000-0003-3691-5774

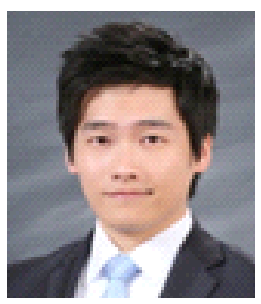

2012년 2월: 인하대학교 컴퓨터정보공학 (공학사)

2013년 1월 현재: LIG넥스원(주) 레이다 연구소 선임연구원

[주 관심분야] 레이다 통제/제어 및 인공 지능 등 
이 성 원 [LIG넥스원/연구원]

https://orcid.org/0000-0001-9425-6581

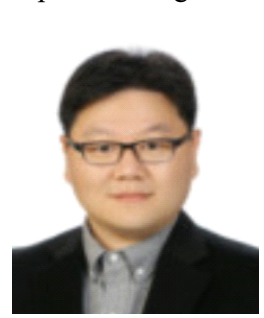

2007년 2월: 아주대학교 정보및컴퓨터공 학과 (공학사)

2009년 2월: 아주대학교 정보통신공학과 (공학석사)

2014년 1월: 아주대학교 정보컴퓨터공학 (공학박사)

2014년 1월 현재: LIG넥스원(주) 레이다 연구소 수석연구원

[주 관심분야] 레이다 통제/제어, 레이다 자원관리, 소프트웨어 아키텍처, 소프트웨어 신뢰성시험 등

박 준 현 [LIG넥스원/연구원]

https://orcid.org/0000-0003-2750-6688

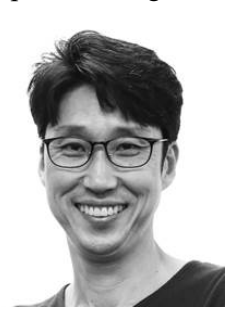

1996년 2월: 홍익대학교 전자공학과 (공학 석사)

1996년 3월 현재: LIG넥스원(주) 레이다 연구소 수석연구원

[주 관심분야] 능동 위상 배열 레이다, 항 공기 레이다, 레이다 신호처리 등
장 성 훈 [국방과학연구소/연구원]

https://orcid.org/0000-0001-9943-2126

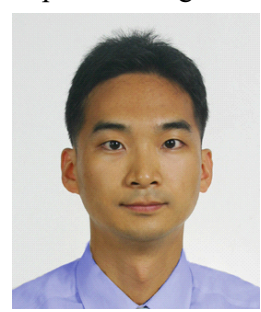

1996년 2월: 서울시립대학교 전자공학과 (공학사)

1998년 2월: 서울시립대학교 전자공학과 (공학석사)

2015년 2월: 서울시립대학교 전자공학과 (공학박사)

1998년 2월 현재: 국방과학연구소 책임 연구원

[주 관심분야] 능동 위상 배열 레이다 시스템, 항공기 레이다 등

김 선 주 [국방과학연구소/연구원]

https://orcid.org/0000-0002-2099-9953

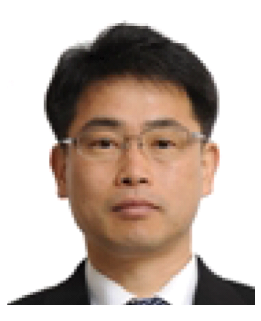

1988년 2월: 아주대학교 전자공학과 (공학 석사)

1988년 3월 현재: 국방과학연구소 책임 연구원

[주 관심분야] 반도체 송수신모듈설계, 능 동 위상 배열 레이다 시스템 설계, 항공 기 레이다 등 